\title{
Protein Arginine Methyltransferase 1 (PRMT1) Selective Inhibitor, TC-E 5003, Has Anti-Inflammatory Properties in TLR4 Signaling
}

\author{
Eunji Kim ${ }^{1}{ }^{1}$, Jiwon Jang ${ }^{1}$, Jae Gwang Park ${ }^{2}$, Kyung-Hee Kim ${ }^{3}$, Keejung Yoon ${ }^{1}$, \\ Byong Chul Yoo ${ }^{2, *(1)}$ and Jae Youl Cho ${ }^{1, *(1)}$ \\ 1 Department of Integrative Biotechnology, Biomedical Institute for Convergence at SKKU (BICS), \\ Sungkyunkwan University, Suwon 16419, Korea; im144069@gmail.com (E.K.); rhea980327@gmail.com (J.J.); \\ keejung@skku.edu (K.Y.) \\ 2 Division of Translational Science, Research Institute, National Cancer Center, Goyang 10408, Korea; \\ wannabejk@naver.com \\ 3 Proteomic Analysis Team, Research Institute, National Cancer Center, Goyang 10408, Korea; \\ kyunghee@ncc.re.kr \\ * Correspondence: yoo_akh@ncc.re.kr (B.C.Y.); jaecho@skku.edu (J.Y.C.); \\ Tel.: +82-31-920-2342 (B.C.Y.); +82-31-290-7876 (J.Y.C.)
}

Received: 5 March 2020; Accepted: 25 April 2020; Published: 26 April 2020

\begin{abstract}
Protein arginine methyltransferase 1 (PRMT1) is the most predominant PRMT and is type I, meaning it generates monomethylarginine and asymmetric dimethylarginine. PRMT1 has functions in oxidative stress, inflammation and cancers, and modulates diverse diseases; consequently, numerous trials to develop PRMT1 inhibitors have been attempted. One selective PRMT1 inhibitor is $N, N^{\prime}$-(Sulfonyldi-4,1-phenylene)bis(2-chloroacetamide), also named TC-E 5003 (TC-E). In this study, we investigated whether TC-E regulated inflammatory responses. Nitric oxide (NO) production was evaluated by the Griess assay and the inflammatory gene expression was determined by conducting RT-PCR. Western blot analyzing was carried out for inflammatory signaling exploration. TC-E dramatically reduced lipopolysaccharide (LPS)-induced NO production and the expression of inflammatory genes (inducible NO synthase (iNOS), cyclooxygenase (COX)-2, tumor necrosis factor (TNF)- $\alpha$ and interleukin (IL)-6) as determined using RT-PCR. TC-E downregulated the nuclear translocation of the nuclear factor (NF)-KB subunits p65 and p50 and the activator protein (AP)-1 transcriptional factor c-Jun. Additionally, TC-E directly regulated c-Jun gene expression following LPS treatment. In NF-kB signaling, the activation of I $\mathrm{B} \alpha$ and Src was attenuated by TC-E. Taken together, these data show that TC-E modulates the lipopolysaccharide (LPS)-induced AP-1 and NF- $\mathrm{kB}$ signaling pathways and could possibly be further developed as an anti-inflammatory compound.
\end{abstract}

Keywords: protein arginine methyltransferase 1 (PRMT1); TC-E 5003; inflammation; AP-1; NF- KB

\section{Introduction}

Inflammation is a biological response against pathogens such as bacteria, fungi and viruses. Immune cells (e.g., macrophages, mast cells, dendritic cells, and neutrophils) recognize damageor pathogen-associated molecular patterns (DAMPs/PAMPs) through innate immune recognition receptors [1,2]. An encounter between the receptors and pathogens initiates the induction of inflammatory signaling pathways to activate the nuclear factor (NF)- $\mathrm{kB}$, activator protein (AP)-1 and interferon regulatory factor (IRF) via phosphorylation [3-5]. In particular, AP-1 activity is commonly regulated by mitogen-activated protein kinases (MAPKs), which are regulated by MAPK kinases (MAPKKs)/transforming growth factor beta-activated kinase 1 (TAK1) [6,7]. The resulting 
activated transcriptional factors regulate the expression of pro-inflammatory genes including cytokines (interleukin (IL)-1 $\beta$, tumor necrosis factor (TNF)- $\alpha$, IL-10), chemokines (eotaxin and macrophage inflammatory protein (MIP)-2) and adhesion molecules (intracellular adhesion molecule (ICAM)-1 and cluster of differentiation (CD29)) to eliminate the pathogen [8,9]. Because dysfunctions of inflammation can cause severe diseases, such as chronic inflammation, arthritis, Alzheimer's disease and metabolic diseases, inflammatory signaling is tightly controlled $[4,10,11]$.

Protein arginine methyltransferases (PRMTs) catalyze arginine methylation and add one or two methyl groups from the methyl donor S-adenosylmethionine (AdoMet) [12,13]. The PRMT family is categorized into four types according to the methylarginine derivative generated [14]. All types of PRMTs can generate monomethylated arginine (MMA). Type I PRMTs (PRMT1, PRMT2, PRMT3, PRMT4, PRMT6, PRMT8) also generate asymmetric dimethylarginines (ADMAs), and type II PRMTs (PRMT5 and PRMT9) can form symmetric dimethylarginines (SDMAs) on substrates. PRMT7 is categorized as type III catalyzing only MMA [14,15]. Some type IV methyltransferases catalyze $\delta$-monomethylarginine on internal nitrogen atoms, but this process is not yet fully understood [16]. PRMTs have various substrates including histones and non-histone proteins [17]. Methylated arginines are involved in diverse biological functions such as transcriptional regulation, DNA repair, signal transduction and protein-protein interactions [16]. Among the methyltransferases, PRMT1 is the most prevalent arginine methyltransferase in mammalians and is responsible for various processes including lymphocyte function, oxidative stress, inflammation and cancer [17-20]. Especially in inflammatory responses, the expression level of PRMT1 was elevated in pulmonary and allergic inflammation [16,21,22]. PRMT1 upregulated the expression of inflammatory genes such as IL-1 $\beta$, IL-6, CXCL (C-X-C motif chemokine) 10, and CXCL8 [22,23]. Moreover, PRMT1 regulated peroxisome proliferator-activated receptor $\gamma(\operatorname{PPAR} \gamma)$-dependent macrophage differentiation and major histocompatibility complex II (MHCII) transcription [24,25]. Since PRMT1 is correlated to diseases and is considered a promising target for therapeutic development, several trials have been conducted to discover PRMT1 inhibitors [26,27]. One of the selective PRMT1 inhibitors is the bis-chloroacetyl amide of dapsone ( $N, N^{\prime}$-(Sulfonyldi-4,1-phenylene)bis(2-chloroacetamide), TC-E 5003, Figure 1a). TC-E 5003 (TC-E) shows inhibition solely of PRMT1 and not PRMT4 or the lysine methyltransferase Set7/9 [28]. Based on previous reports that studied the roles of PRMT1 in inflammation [29,30], we investigated the anti-inflammatory roles of TC-E in lipopolysaccharide (LPS)-induced RAW264.7 cells. The production of the inflammatory mediator nitric oxide (NO) and the expression levels of inflammatory genes were measured using Griess assays and RT-PCR, respectively. The activations of the inflammatory AP- 1 and NF- $\mathrm{KB}$ pathways were verified using Western blotting.<smiles>O=C(CCl)Nc1ccc(S(=O)(=O)c2ccc(NC(=O)CCl)cc2)cc1</smiles>

(a)

Figure 1. Cont. 


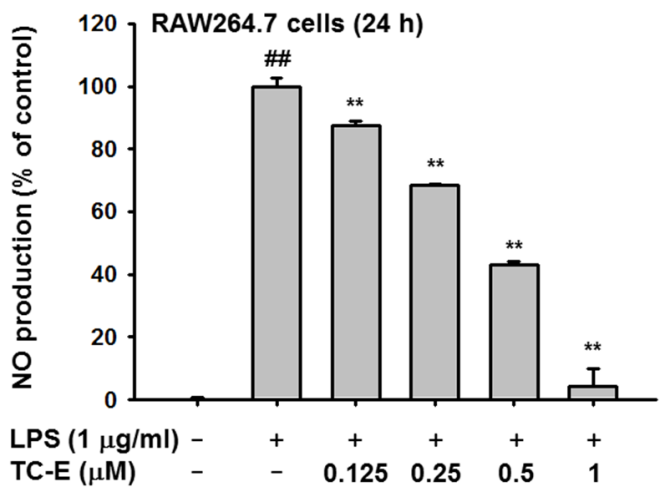

(b)

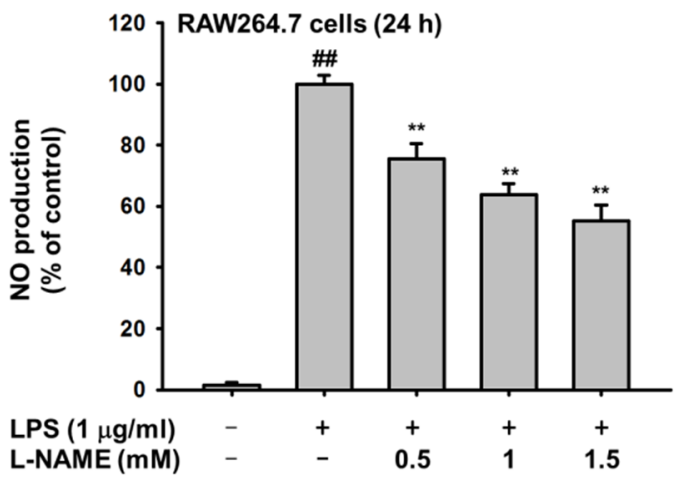

(d)

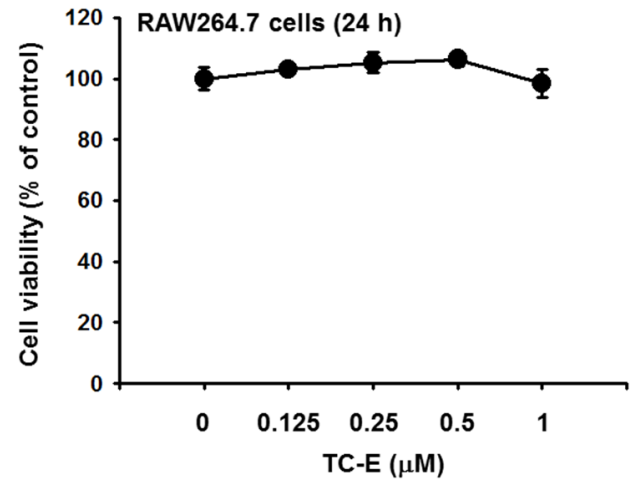

(c)

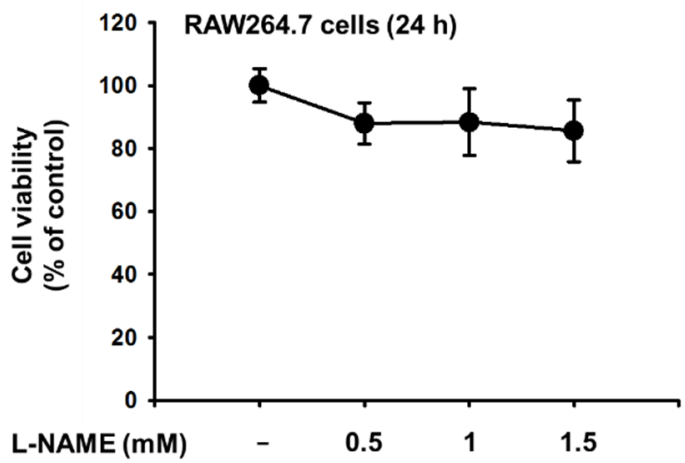

(e)

Figure 1. NO production levels in TC-E-treated RAW264.7 cells. (a) Structure of $N, N^{\prime}$-(Sulfonyldi-4,1-phenylene)bis(2-chloroacetamide) or TC-E 5003 (TC-E). RAW264.7 cells were pre-treated with TC-E $(0-1 \mu \mathrm{M})($ b) or NG-Nitro-L-arginine Methyl Ester (L-NAME) (0-1.5 mM) (d) for $30 \mathrm{~min}$, and LPS $(1 \mu \mathrm{g} / \mathrm{mL})$ was added for $24 \mathrm{~h}$. Supernatants were collected, and the production of $\mathrm{NO}$ was analyzed using the Griess assay. Optical density at $570 \mathrm{~nm}$ was measured using spectrometry. The cytotoxicity of TC-E $(0-1 \mu \mathrm{M})(\mathbf{c})$ and L-NAME $(0-1.5 \mathrm{mM})(\mathbf{e})$ were tested using the 3-(4,5-dimethylthiazol-2-yl)-2,5-diphenyltetrazolium bromide (MTT) assay. The data (b,c,d) are expressed as the means \pm SEM of the experiments, performed three independent times with five $(\mathbf{b}, \mathbf{d})$ or three (c,e) samples. All the experiments were performed at least three times with at least three samples. TC-E, TC-E 5003; LPS, lipopolysaccharide; NO, nitric oxide. ${ }^{\# \#} p<0.01$ compared to normal group and ${ }^{* *} p<0.01$ compared LPS-induced group. Statistical significance was analyzed by ANOVA and Kruskal-Wallis test.

\section{Results}

\subsection{The Effects of TC-E on NO Production}

To determine whether TC-E has anti-inflammatory effects, NO production in RAW264.7 cells was measured after exposure to LPS. TC-E significantly and dose-dependently decreased NO production without cytotoxicity (Figure 1b,c). The reducing effect of TC-E on NO production was analyzed by ANOVA coupled with a Kruskal-Wallis test expressed as mean \pm SD. Under the same conditions, the nitric oxide synthase (NOS) inhibitor NG-Nitro-L-arginine Methyl Ester (L-NAME) also suppressed NO production without cytotoxicity (Figure 1d,e). These results showed that TC-E suppressed LPS-induced NO production. 


\subsection{The Effects of TC-E on Pro-Inflammatory Gene Expression}

To confirm that the anti-inflammatory effects of TC-E were the result of transcriptional regulation, the mRNA expression levels of several inflammatory cytokines and mediators were determined using RT-PCR. The expression of inducible NO synthase (iNOS) was remarkably reduced by TC-E and the expressions of COX-2, TNF- $\alpha$, IL-1 $\beta$ and IL-6 were also downregulated (Figure 2a). Because TC-E downregulated the transcription of inflammatory genes, nuclear proteins were prepared from LPS-treated RAW264.7 cells. After treatment with LPS for 15, 30, or $60 \mathrm{~min}$, the nuclear translocation of the inflammatory AP-1 and NF- $\mathrm{kB}$ subunits was determined using immunoblotting. c-Jun, a subunit of the AP-1 transcriptional factor, had less translocation at $30 \mathrm{~min}$ following TC-E treatment (Figure $2 \mathrm{~b}$ ). In the case of NF- $\mathrm{kB}$, the translocation of p65 and p50 into the nucleus was suppressed at $15 \mathrm{~min}$ of the LPS treatment (Figure 2c). Taken together, these data indicate that TC-E has the ability to regulate inflammatory responses through transcription inhibition.

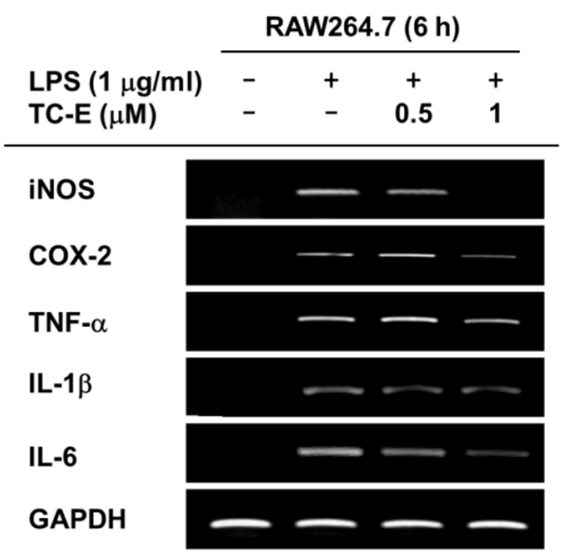

(a)
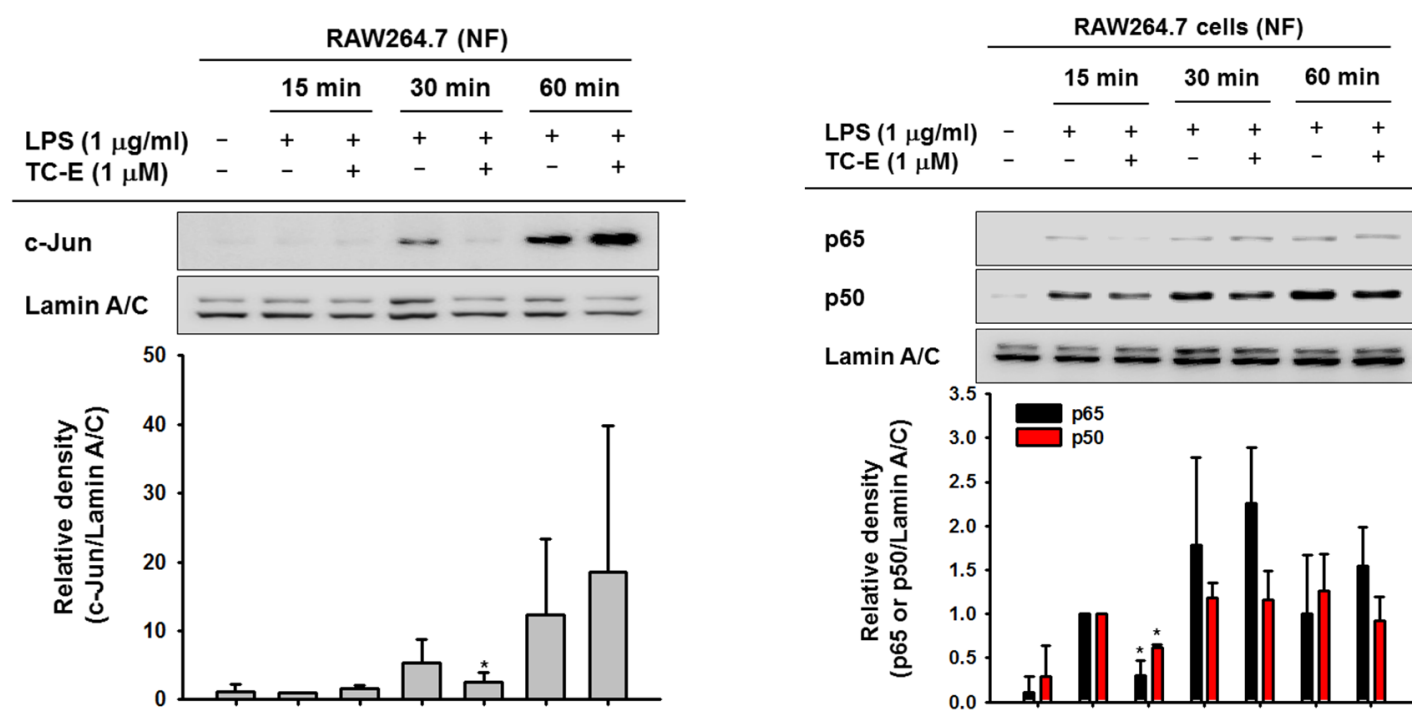

(b)

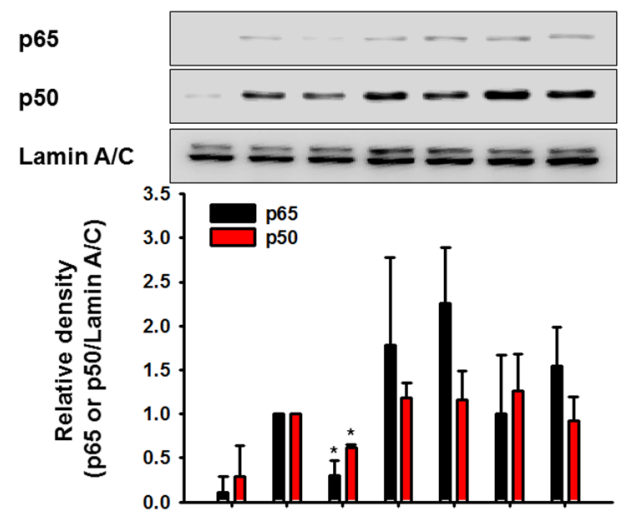

(c)

Figure 2. Anti-inflammatory effects of TC-E at the transcriptional level. (a) Expression levels of the inflammatory genes in RAW264.7 cells treated with LPS for 6 h. $(\mathbf{b}, \mathbf{c})$ RAW264.7 cells were pre-treated with TC-E then exposed to LPS for various amount of time (0-60 $\mathrm{min})$. Nuclear translocation of the c-Jun subunit of AP-1 (b) and the p65 and p60 subunits of NF- $\mathrm{BB}$ (c) was determined using immunoblotting with Lamin A/C as a standard. All the experiments were performed at least three times with at least three samples. Relative intensity in the bottom panels of $b$ and $c$ is expressed as the mean \pm SEM of the data measured and quantified using image J with three different blots of three different samples. iNOS, 
inducible nitric oxide synthase; COX-2, cyclooxygenase-2; TNF- $\alpha$, tumor necrosis factor- $\alpha$; IL- $1 \beta$, interleukin $1 \beta$; IL-6, interleukin 6; GAPDH, glyceraldehyde 3-phosphate dehydrogenase; TC-E, TC-E 5003; LPS, lipopolysaccharide; NF, nuclear fraction. ${ }^{*} p<0.05$ compared LPS-induced group at each time point. Statistical significance was analyzed by ANOVA and Kruskal-Wallis test.

\subsection{The Regulatory Effects of TC-E on the AP-1 Signaling Pathway}

Based on previous results (Figure $2 b$ ), we determined the regulatory mechanism of TC-E in the inflammatory AP-1 signaling pathway. MAPKs are phosphorylated and activated by LPS, and the signal is transduced to AP-1 subunits through phosphorylation [6,31-33]. We examined the phosphorylation levels of c-Jun and MAPKs in the LPS-treated RAW264.7 cells lysates (Figure 3a). The levels of p-c-Jun were decreased by TC-E at 15 and $30 \mathrm{~min}$ of exposure to LPS. However, the phosphorylated forms of the MAPKs were not affected by TC-E at any time point. This indicated that TC-E exclusively modulated the amount of nuclear c-Jun but did not affect the phosphorylated forms of MAPKs. Moreover, TC-E suppressed the c-Jun transcription in RAW264.7 cells after 15 min of LPS treatment (Figure 3b). To confirm the inhibitory effect of TC-E on c-Jun, the c-Jun expression levels were determined under PRMT1-knockdown conditions (Figure 3c). The total c-Jun expression was clearly reduced in short hairpin RNA to PRMT1 (shPRMT1)-expressing RAW264.7 cells by LPS exposure. Taken together, these data showed that TC-E regulates LPS-induced AP-1 transcriptional activity by modulating the c-Jun gene expression.

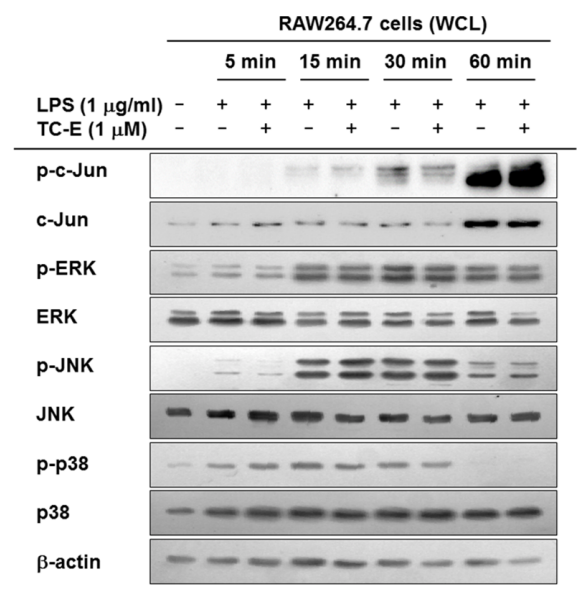

(a)

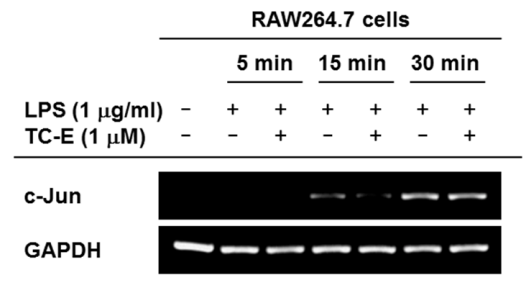

(b)

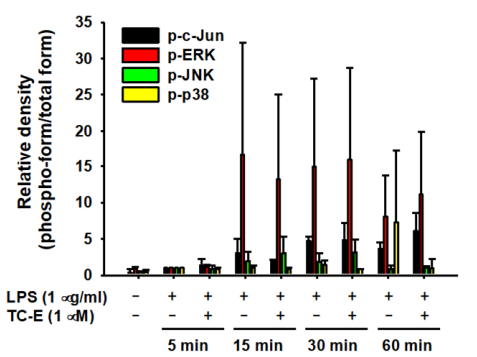

(a)

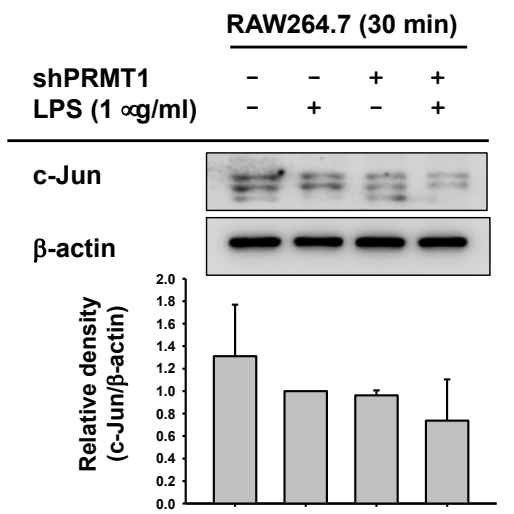

(c)

Figure 3. Regulatory mechanism of TC-E on activator protein (AP)-1 activity. (a) RAW264.7 cells were pre-treated with TC-E for $30 \mathrm{~min}$ then treated with LPS for various amounts of time. Whole cell lysates 
were harvested and used for immunoblotting with the phospho- and total antibodies against c-Jun, ERK, JNK and p38 with $\beta$-actin as a standard. (b) The gene expression level of c-Jun was evaluated in the presence or absence of TC-E in RAW264.7 cells treated with LPS for various amounts of time. (c) Scrambled- or PRMT1-knockdown RAW264.7 cells were exposed to LPS $(1 \mu \mathrm{g} / \mathrm{mL})$ for $30 \mathrm{~min}$. Whole cell lysates were then collected, and the expression level of c-Jun was determined using immunoblotting. Relative intensity in the right panel of a and the bottom panel of $\mathrm{c}$ is expressed as means \pm SEM of the data measured and quantified using image J with the three different blots of three different samples. Statistical significance was analyzed by ANOVA and Kruskal-Wallis test. ERK, extracellular signal-regulated kinase; JNK, c-Jun N-terminal kinase; GAPDH, glyceraldehyde 3-phosphate dehydrogenase; PRMT1, protein arginine methyltransferase 1; TC-E, TC-E 5003; LPS, lipopolysaccharide; WCL, whole cell lysates.

\subsection{The Regulatory Effects of TC-E on the NF-אB Signaling Pathway}

NF- $\mathrm{kB}$ signaling was also explored to verify the regulatory mechanism of TC-E. Phosphorylated I $\mathrm{K} \mathrm{\alpha}$ was significantly downregulated by TC-E after $5 \mathrm{~min}$ of LPS treatment (Figure $4 \mathrm{a}$ ). Therefore, we ascertained the activation of Src and Syk kinases, which are upstream molecules of the NF- $\mathrm{kB}$ signaling pathway, at earlier time points. RAW264.7 cells were treated with LPS for 2, 3, or $5 \mathrm{~min}$, and the activated levels of Src and Syk kinases were observed. (Figure 4b). Although the phosphorylation of both the Src and Syk kinases was activated by LPS, only Src phosphorylation was inhibited by TC-E after 2 min of LPS treatment. Based on these data, we provisionally hypothesized that the Src kinase was a target of TC-E and conducted Src-overexpression experiments and cellular thermal shift assays (CETSAs) using human embryonic kidney 293T (HEK293T) cells. To investigate the role of TC-E on the expected target protein, Src kinase, we set up the Src-overexpressed HEK293T cells to focus on the interested protein because RAW264.7 cells were known to be fastidious for transfection [34,35]. However, the phosphorylation of Src was not altered by TC-E (Figure 4c), and there was no difference in Src stability with or without TC-E (Figure 4d). These results indicated that TC-E modulated Src activity but not in a direct manner. We also confirmed that the inhibitory effects of TC-E were mediated through the PRMT1 regulation. As shown in Figure 4e, Src was not activated by LPS in the PRMT1-knockdown cells but was activated in scrambled-knockdown cells. Taken together, these data show that TC-E exerts an anti-inflammatory effect by controlling the NF-kB signaling pathway. 


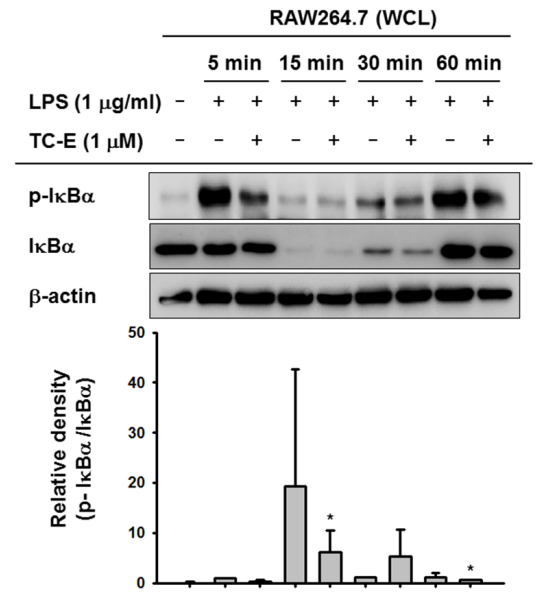

(a)

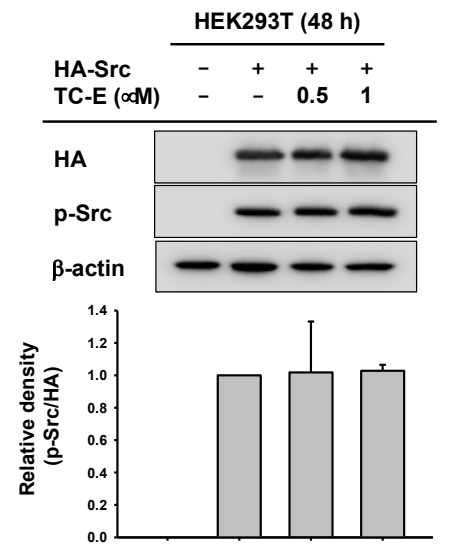

(c)

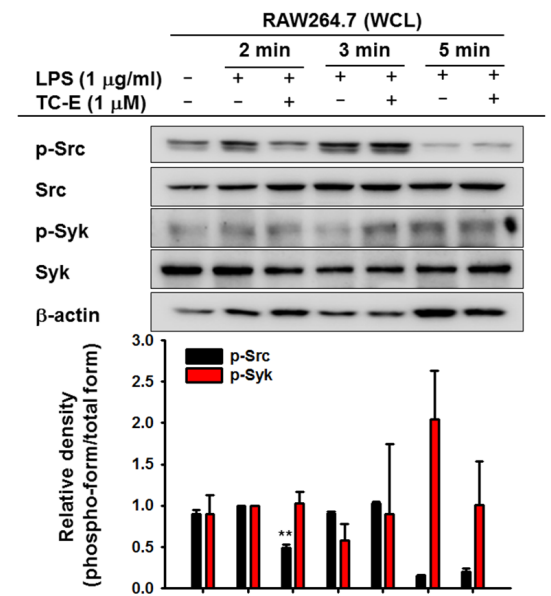

(b)

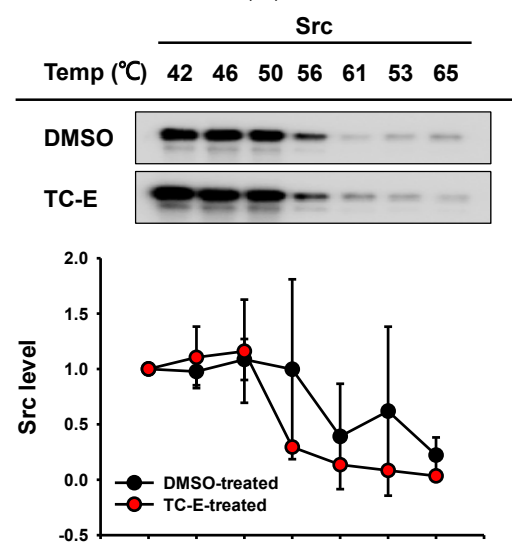

(d)
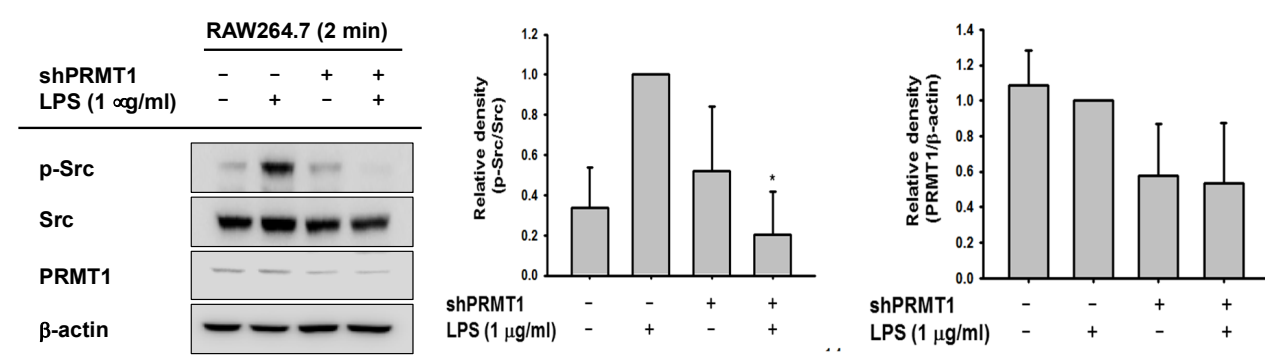

(e)

Figure 4. Regulatory mechanism of TC-E on NF-kB activity. (a) TC-E-treated RAW264.7 cells were exposed to LPS for various amounts of time (0-60 min), and the whole cell lysates were used to determine I $\kappa \mathrm{B} \alpha$ phosphorylation. (b) The anti-inflammatory effects of TC-E were also determined in the RAW264.7 cells treated with LPS for shorter amounts of time (0-5 min). The activities of Src and Syk were determined using immunoblotting. (c) human embryonic kidney 293T (HEK293T) cells were transfected with HA-Src for $24 \mathrm{~h}$ and then treated with TC-E for an additional $24 \mathrm{~h}$. The cells were then harvested, lysed and subjected to immunoblotting using the antibodies against HA and the phosphorylated Src with $\beta$-actin as a standard. (d) HEK293T cells overexpressing HA-Src were incubated for $24 \mathrm{~h}$ in the presence or absence of TC-E $(1 \mu \mathrm{M})$. The cells were collected with phosphate-buffered saline (PBS) and aliquoted into 0.2-mL tubes containing the same number of cells. The samples were heated at temperatures ranging from 42 to $65^{\circ} \mathrm{C}$, and the levels of Src were determined using immunoblotting. (e) Scrambled- or shPRMT1-expressing RAW264.7 cells were treated with LPS $(1 \mu \mathrm{g} / \mathrm{mL})$ for $2 \mathrm{~min}$. Whole cell lysates were used for immunoblotting with the antibodies against phospho-Src, total Src and PRMT1 with $\beta$-actin as a standard. All the experiments 
were performed at least three times. Relative intensity in the bottom panels of $(\mathbf{a}, \mathbf{c}, \mathbf{d})$, the middle panel of $e$, and the right panels of $b$ and e is expressed as means \pm SEM of the data measured and quantified using image $\mathrm{J}$ with the three different blots of three different samples. Statistical significance was analyzed by ANOVA and a Kruskal-Wallis test. ${ }^{*} p<0.05$ compared to control groups treated with LPS alone at each time point or vehicle control. DMSO, dimethyl sulfoxide; PRMT1, protein arginine methyltransferase 1; TC-E, TC-E 5003; LPS, lipopolysaccharide; WCL, whole cell lysates.

\section{Discussion}

We explored the anti-inflammatory effects of the PRMT1 inhibitor TC-E under LPS induction. TC-E clearly diminished the LPS-mediated NO production (Figure 1) and the transcription of the inflammatory gene was also regulated by TC-E (Figure 2). TC-E modulated the AP-1 transcriptional factor activation by suppressing the c-Jun expression (Figure 3). NF-KB signaling was also downregulated by suppressing the activation of Src kinases (Figure 4). These data show that TC-E exerts anti-inflammatory effects by controlling inflammatory molecules in diverse ways (Figure 5).

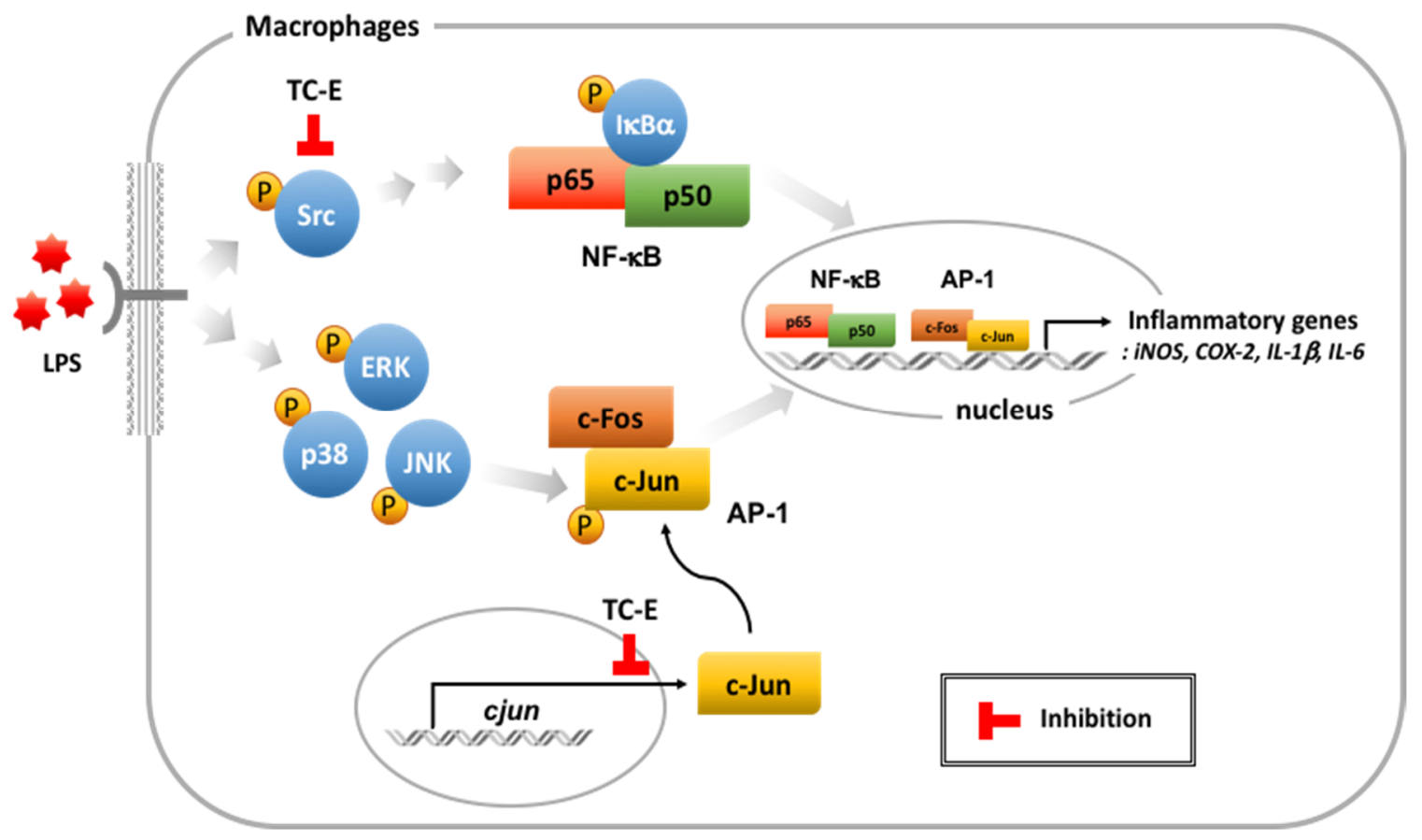

Figure 5. Inhibitory pathway of TC-E in the LPS-induced inflammatory responses. TC-E suppresses the NF- $\mathrm{kB}$ signaling by regulating the Src activation. Gene expression of c-Jun is inhibited by TC-E treatment under the LPS-mediated inflammatory conditions. NF- $\kappa \mathrm{B}$, nuclear factor $\kappa \mathrm{B} ; \mathrm{AP}-1$, activator factor 1; ERK, extracellular signal-regulated kinase; JNK, c-Jun N-terminal kinase; iNOS, inducible nitric oxide synthase; COX-2, cyclooxygeanse-2; IL-1 $\beta$, interleukin $1 \beta$; IL-6, interleukin 6; TC-E, TC-E 5003; LPS, lipopolysaccharide.

TC-E regulated the c-Jun activity at the transcriptional level (Figure 3b) leading to less activation of downstream inflammatory genes such as iNOS, COX-2 and IL-6. Confirming with PRMT1 knock-down cells, there was a much lower level of total c-Jun. Since PRMT1 dimethylates histone 4 at arginine 3 (H4R3), gene expression can be altered by PRMT1. PPAR $\gamma$ is a key transcriptional factor in M2 macrophage polarization for retaining anti-inflammatory states [36,37]. PRMT1 dimethylates the H4R3 associated with the PPAR $\gamma$ gene resulting in the downregulation of the PPAR $\gamma$ response to the IL-4 treatment [37]. In the case of hypoxia, PRMT1 represses the recruiting of both specificity protein 1 (Sp1) and Sp3 transcriptional factors on the hypoxia-inducible transcription factor (HIF)- $1 \alpha$ promoter sites [38]. As these previous reports have shown, it is possible that PRMT1 regulates the 
inflammatory AP-1 transcriptional activity by suppressing the c-Jun subunit availability under early LPS-induced inflammatory conditions. Moreover, we suggested a new regulatory mechanism of c-Jun by PRMT1. Although there are few reports regarding the correlation of c-Jun or other AP-1 transcription factors with PRMT1, one study showed that PRMT1-mediated arginine methylated c-Jun coactivator RING domain AP-1 co-activator-1 (RACO-1) is required for the c-Jun/AP-1 activation [39]. It remains necessary to accurately determine the mechanism of PRMT1 regarding c-Jun/AP-1 activity, but this study demonstrated that PRMT1 activated the LPS-induced inflammatory responses and that TC-E might directly target c-Jun transcriptional activity.

In NF-kB signaling, the phosphorylation of Src was clearly decreased by TC-E after LPS exposure for $2 \mathrm{~min}$ (Figure 2b). Src is considered an upstream molecule in NF-KB signaling and is directly regulated by various anti-inflammatory reagents $[1,40,41]$. However, in this study, TC-E did not directly bind to or control Src kinase activity (Figure 4c,d). Src can be activated by protein kinase $C$ (PKC) $\gamma$ or be regulated by protein tyrosine phosphatase (PTP) or C-terminal Src kinase (CSK) [42,43]. In particular, PTPs dephosphorylate tyrosine 527 (Y527) of Src, which is an auto-inhibitory residue, causes a conformation change [42,44]. In toll-like receptor 4 (TLR4) signaling, the activity of Src kinases is also regulated by receptor tyrosine kinases (RTKs) such as human epidermal growth factor receptor 2 (HER2), platelet-derived growth factor receptor, [43,45] or TNF receptor-associated factor 6 (TRAF6) [46]. It is possible that TC-E regulates other factors to control the TLR4-mediated Src activation in an indirect way. In our previous report, a plant extract suppressed Src activity, not by direct targeting, but via TLR4/MyD88 signal transduction [47].

The trials to develop PRMT inhibitors have been processed because PRMT is one of the prime targets for diverse diseases. AMI-1 (7,7'-carbonylbis(azanediyl)bis(4-hydroxynaphthalene-2-sulfonic acid), a pan PRMT inhibitor, was widely used for studying the biological functions of PRMT1, e.g., pulmonary inflammation, multidrug resistance or RNA processing [48,49]. However, there is a limit to define the accurate roles of PRMT1 by treating this inhibitor, so selective PRMT1 inhibitors were developed and utilized, including furamidine, allantodapsone or MS023 [50-52]. TC-E was one of the chemicals developed to specifically inhibit PRMT1 activity and has been used to study the role of PRMT1 in myogenesis and hyperglycemia [53,54]. The inhibitory activity of TC-E in inflammatory responses has not yet been completely understood. In this study, we proved that the TLR4-mediated inflammatory c-Jun (Figure 2b) and NF-kB (Figure 2c) activation was suppressed by treatment with TC-E. It has been widely reported that PRMT1 upregulates inflammatory genes and is involved in inflammatory responses $[30,48,55]$. Overall, this study suggested that PRMT1 is a potential target for treating inflammatory diseases and that TC-E specifically could be suitable as an anti-inflammatory drug.

In conclusion, TC-E regulates inflammatory responses by inhibiting the c-Jun expression and NF- $\mathrm{kB}$ signal transduction. By downregulating these transcriptional factors, the expression of various inflammatory genes is also inhibited. Collectively, these results show that TC-E has potential for development as an anti-inflammatory compound that targets Src or c-Jun activation.

\section{Materials and Methods}

\subsection{Materials}

TC-E 5003 was purchased from Tocris Bioscience (Bristol, UK). RAW264.7 cells, concatenation of Bagg and Albino (BALB/c)-derived murine macrophage cell line (No. TIB-71), and HEK293T cells and a human embryonic kidney cell line (No. CRL-3216) were acquired from American Type Culture Collection (ATCC) (Rockville, MD, USA). Lipopolysaccharide (LPS, Escherichia coli 0111:B4), L-NAME (NG-Nitro-L-arginine Methyl Ester), puromycin and polyethylenimine (PEI) were obtained from Sigma (St. Louis, MO, USA). 3-(4,5-dimethylthiazol-2-yl)-2,5-diphenyltetrazolium bromide (MTT) was purchased from Amresco (Solon, OH, USA). Fetal bovine serum (FBS) was purchased from Biotechnics Research (Lake Forest, CA, USA), and Roswell Park Memorial Institute 1640 (RPMI1640) 
and Dulbecco's Modified Eagle Medium (DMEM) were obtained from HyClone (Grand Island, NY, USA). Antibodies against the total or phosphorylated forms of c-Jun, p65, p50, IkB $\alpha$, Src, Syk, p38, extracellular signal-regulated kinase (ERK), Lamin A/C, and $\beta$-actin were purchased from Cell Signaling (Beverly, MA, USA). The antibodies against the total and phosphorylated forms of c-Fos, c-Jun N-terminal kinase (JNK) and HA were acquired from Santa Cruz Biotechnology Inc. (Dallas, TX, USA).

\subsection{Cell Culture}

RAW264.7 cells were cultured in an RPMI1640 medium containing 10\% heat-inactivated FBS and 1\% penicillin-streptomycin. HEK293T cells were incubated in DMEM supplemented with 5\% heat-inactivated FBS and 1\% penicillin-streptomycin. All the cells were maintained in a $5 \% \mathrm{CO}_{2}$ humidified incubator at $37^{\circ} \mathrm{C}$.

\subsection{NO Production and Griess Assay}

RAW264.7 cells $\left(1 \times 10^{6}\right.$ cells $\left./ \mathrm{mL}\right)$ were plated in 96-well plates and incubated overnight. The cells were pre-treated with TC-E $(0-1 \mu \mathrm{M})$ or L-NAME $(0-1.5 \mathrm{mM})$ for $30 \mathrm{~min}$, and then LPS $(1 \mu \mathrm{g} / \mathrm{mL})$ was added. The cells were incubated for an additional $24 \mathrm{~h}$, and the supernatants of the cells were collected to determine the levels of NO production using the Griess assay as previously reported [56,57].

\subsection{Cell Viability Assay}

RAW264.7 cells $\left(1 \times 10^{6}\right.$ cells $\left./ \mathrm{mL}\right)$ or HEK293T cells $\left(5 \times 10^{5}\right.$ cells $\left./ \mathrm{mL}\right)$ were plated in 96-well plates and treated with TC-E or L-NAME at various concentrations for $24 \mathrm{~h}$. The conventional MTT assays were then performed as previously described [58,59].

\subsection{Preparation of mRNA and Semiquantitative PCR}

RAW264.7 cells $\left(1 \times 10^{6}\right.$ cells/well $)$ were plated on 12-well plates and incubated overnight. TC-E-pre-treated cells were exposed to LPS for the indicated time points. The medium was discarded, and the total RNA was isolated from the cells with TRIzol reagent following the manufacturer's instructions. Using these mRNA, reverse transcription PCR was performed as previously described [60]. Briefly explained, complementary DNA (cDNA) was synthesized using RevertAid First Strand cDNA synthesis kit (Thermo Fisher Scientific, Waltham, MA, USA). The synthesized cDNA was used for amplifying the target genes with specific primers and the PCRBIO HS Taq PreMix (PCR Biosystems, London, United Kingdom) in thermal cycler (Life Technologies, Carlsbad, CA, USA). The PCR reaction was conducted with the incubation mixture $\left(2 \mu \mathrm{L}\right.$ cDNA, $4 \mu \mathrm{M} 5^{\prime}$ and $3^{\prime}$ primers, a $10 \times$ buffer $(10 \mathrm{mM}$ of Tris-Hydrogen chloride (HCl), pH 8.3, $50 \mathrm{mM}$ of KCl, $0.1 \%$ Triton X-100), $250 \mu \mathrm{M}$ of dNTP, $25 \mathrm{mM}$ of $\mathrm{MgCl}_{2}$, and 1 unit of Taq) under the following incubation conditions (a $45 \mathrm{~s}$ denaturation time at $94{ }^{\circ} \mathrm{C}$, an annealing time of $45 \mathrm{~s}$ between 55 to $60^{\circ} \mathrm{C}$, an extension time of $60 \mathrm{~s}$ at $72{ }^{\circ} \mathrm{C}$, and a final extension of $7 \mathrm{~min}$ at $72{ }^{\circ} \mathrm{C}$ at the end of 30 cycles). The primers (Bioneer, Seoul, Korea) used in this experiment are indicated in Table 1 (F: forward, R: reverse). 
Table 1. Sequences of the primers of the investigated genes in a RT-PCR analysis.

\begin{tabular}{|c|c|c|}
\hline Gene & & Primer Sequences \\
\hline \multirow{2}{*}{$T N F-\alpha$} & $\mathrm{F}$ & 5'-TTGACCTCAGCGCTGAGTTG-3' \\
\hline & $\mathrm{R}$ & 5'-CCTGTAGCCCACGTCGTAGC-3' \\
\hline \multirow{2}{*}{$I L-1 \beta$} & $\mathrm{F}$ & 5'-CAGGATGAGGACATGAGCACC-3' \\
\hline & $\mathrm{R}$ & 5'-CTCTGCAGACTCAAACTCCAC-3' \\
\hline \multirow{2}{*}{$I L-6$} & $\mathrm{~F}$ & 5'-GTACTCCAGAAGACCAGAGG-3' \\
\hline & $\mathrm{R}$ & 5'-TGCTGGTGACAACCACGGCC-3' \\
\hline \multirow{2}{*}{ iNOS } & $\mathrm{F}$ & 5'-CCCTTCCGAAGTTTCTGGCAGCAGC-3‘ \\
\hline & $\mathrm{R}$ & 5‘-GGCTGTCAGAGCCTCGTGGCTTTGG-3` \\
\hline \multirow{2}{*}{$\mathrm{COX}-2$} & $\mathrm{~F}$ & 5'-CACTACATCCTGACCCACTT-3' \\
\hline & $\mathrm{R}$ & 5'-ATGCTCCTGCTTGAGTATGT-3' \\
\hline \multirow{2}{*}{ c-Jun } & $\mathrm{F}$ & $5^{\prime}-$ ACGACCTTCTACGACGATGC-3' \\
\hline & $\mathrm{R}$ & 5' - CCAGGTTCAAGGTCATGCTC-3' \\
\hline \multirow{2}{*}{ GAPDH } & $\mathrm{F}$ & 5'-CACTCACGGCAAATTCAACGGCAC-3' \\
\hline & $\mathrm{R}$ & 5'-GACTCCACGACATACTCAGCAC-3' \\
\hline
\end{tabular}

\subsection{Plasmid Transfection}

HEK293T cells $\left(3 \times 10^{5}\right.$ cells $\left./ \mathrm{mL}\right)$ were seeded in 12 -well plates to make $70 \%-80 \%$ cell confluency. The cells were then transfected with HA-Src plasmids using PEI for $24 \mathrm{~h} \mathrm{[61]}$, and then were treated with TC-E for an additional $24 \mathrm{~h}$. After the HEK293T cells were harvested and utilized for analyzing proteins or CETSA.

\subsection{Preparation of Nuclear Fraction}

The cells were harvested with PBS and centrifuged (12,000 rpm for $1 \mathrm{~min})$ once. PBS was removed, and $400 \mu \mathrm{L}$ of Buffer A (10 mM HEPES, pH 7.8 with $\mathrm{KOH} ; 10 \mathrm{mM} \mathrm{KCl} ; 2 \mathrm{mM} \mathrm{MgCl} 2 ; 0.1 \mathrm{mM}$ ethylenediaminetetraacetic acid (EDTA); $1 \mathrm{mM}$ DTT; $0.1 \mathrm{mM}$ PMSF; $2 \mu \mathrm{g} / \mathrm{mL}$ leupeptin; $2 \mu \mathrm{g} / \mathrm{mL}$ aprotinin) was added for washing and then discarded. The cells were added with Buffer A again with $25 \mathrm{~mL} \mathrm{10 \%} \mathrm{NP-40,} \mathrm{and} \mathrm{vortexted} \mathrm{vigorously} \mathrm{for} 30 \mathrm{~s}$. The cells were centrifuged at 14,000 rpm for $30 \mathrm{~s}$, and the supernatants were carefully discarded. Pellets (nuclear fraction) were washed with Buffer A and suspended with Buffer B (10 mM HEPES, pH 7.8 with KOH; $50 \mathrm{mM} \mathrm{KCl} ; 300 \mathrm{mM} \mathrm{NaCl} ; 0.1 \mathrm{mM}$ EDTA; $1 \mathrm{mM}$ DTT; $0.1 \mathrm{mM}$ PMSF; $2 \mu \mathrm{g} / \mathrm{mL}$ leupeptin; $2 \mu \mathrm{g} / \mathrm{mL}$ aprotinin; $10 \%(v / v)$ glycerol). The nuclear proteins were incubated at $4{ }^{\circ} \mathrm{C}$ for $20 \mathrm{~min}$ vortexing every $5 \mathrm{~min}$ and stored at $-80^{\circ} \mathrm{C}$ until use.

\subsection{Preparation of Whole Cell Lysates}

The cells were washed with PBS once, collected, transferred to fresh tubes and centrifuged at $12,000 \mathrm{rpm}$ for $5 \mathrm{~min}$ at $4{ }^{\circ} \mathrm{C}$. The cells were lysed with lysis buffer $(20 \mathrm{mM}$ Tris-HCl, pH 7.4; $2 \mathrm{mM}$ EDTA; $2 \mathrm{mM}$ ethyleneglycotetraacetic acid (EGTA); $1 \mathrm{mM}$ DTT; $50 \mathrm{mM} \beta$-glycerol phosphate; $0.1 \mathrm{mM}$ sodium vanadate; $1.6 \mathrm{mM}$ pervanadate; $1 \%$ Triton X-100; $10 \%$ glycerol; $10 \mu \mathrm{g} / \mathrm{mL}$ aprotinin; $10 \mu \mathrm{g} / \mathrm{mL}$ pepstatin; $1 \mu \mathrm{M}$ benzamide; and $2 \mu \mathrm{M}$ PMSF). The protein lysates were then pelleted using centrifugation at $12,000 \mathrm{rpm}$ for $5 \mathrm{~min}$ at $4{ }^{\circ} \mathrm{C}$. The resulting supernatants were used for Western blotting.

\subsection{Western Blotting Analysis}

The total cell lysates or nuclear fraction were prepared from RAW264.7 cells or HEK293T cells under the indicated conditions. The protein samples were separated by sodium dodecyl sulfate-polyacrylamide gel electrophoresis (Bio-Rad, Hercules, CA, USA), and immunoblotting was performed with specific antibodies, as reported previously [62]. The nuclear fractions were analyzed with antibodies against the phosphorylated or total forms of c-Jun, p65, p50, and Lamin A/C. With whole cell lysates, the protein levels were examined with antibodies against the phosphorylated or total forms of c-Jun, ERK, JNK, p38, IKB $\alpha$, Src, Syk, PRMT1, HA, and $\beta$-actin. The band intensity in each blot was measured and quantified using image J (Ver. 2) (the National Institutes of Health and the 
Laboratory for Optical and Computational Instrumentation (LOCI, University of Wisconsin, Madison, WI, USA).

\subsection{Lentivirus-Mediated Knockdown (shRNA)}

Plasmids containing short hairpin RNA (shRNA) coding sequences against either mouse prmt1 or a non-targeting scrambled sequence (Table 2) were cloned into the pLKO.1 puro vector (a gift from Prof. Yoon, Sungkyunkwan University, Suwon, Republic of Korea) according to the Addgene protocol (www.addgene.org). The lentivirus was then produced by the transient transfection of the HEK293T cells. The generated viruses were used to infect the RAW264.7 cells, and the cells infected with either shScrambled or shPRMT1 were selected using puromycin $(2.5 \mu \mathrm{g} / \mathrm{mL})$ treatment. The knockdown level of the selected cells was confirmed using immunoblotting.

Table 2. The primers for short hairpin RNA (shRNA) sequences

\begin{tabular}{cc}
\hline Gene & Sequences \\
\hline shScrambled & TCCTAAGGTTAAGTCGCCCTCG \\
shPRMT1 & CATGATGCAGTTCGCGGCCTCGG \\
\hline
\end{tabular}

\subsection{Statical Analysis}

Since our experimental sample scale in this study is not enough to follow up the normal distribution pattern, all the results were analyzed by a non-parametric test using analysis of variance (ANOVA) coupled with the Kruskal-Wallis test. $p$-values $<0.05$ were considered statistically significant. The data (Figure $1 \mathrm{~b}-\mathrm{d}$ ) presented in this paper are expressed as the means \pm SEM of the experiments, performed three independent times with five (Figure 1b,d) or three (Figure 1c,e) samples. The data (bottom and right panels of Figure $2 b, c$, Figure $3 a, c$, and Figure $4 a-e$ ) are expressed as the mean \pm SEM of the relative band intensity values, obtained by Image J, with three different blots of independently prepared three samples. Similar experimental cellular and immunoblotting data were also observed using an additional independent set of experiments that was conducted using the same numbers of experimental samples. All of the statistical tests were carried out using the computer program SPSS (Ver. 24, SPSS Inc., Chicago, IL, USA).

Author Contributions: E.K., B.C.Y. and J.Y.C. conceived and designed the experiments; E.K., J.J., J.G.P., and K.-H.K. performed the experiments; E.K., K.Y., B.C.Y., and J.Y.C. analyzed the data; E.K., B.C.Y., and J.Y.C. wrote the paper. All authors have read and agreed to the published version of the manuscript.

Funding: This research was supported by the Basic Science Research Program through the National Research Foundation of Korea (NRF) funded by the Ministry of Education (NRF-2019R1I1A1A01062413) and by grants from the National Cancer Center in Korea (1910294), Republic of Korea.

Conflicts of Interest: The authors declare no conflict of interest. The funders had no role in the design of the study; in the collection, analyses, or interpretation of data; in the writing of the manuscript, or in the decision to publish the results.

\section{Abbreviations}

$\begin{array}{ll}\text { ADMA } & \text { Asymmetric dimethylarginine } \\ \text { AdoMet } & \text { S-Adenosylmethionine } \\ \text { AP-1 } & \text { Activator protein 1 } \\ \text { CETSA } & \text { Cellular thermal shift assay } \\ \text { CSK } & \text { C-terminal Src kinase } \\ \text { DAMPs } & \text { Damage-associated molecular patterns } \\ \text { EDTA } & \text { Ethylenediaminetetraacetic acid } \\ \text { EGTA } & \text { Ethyleneglycotetraacetic acid } \\ \text { ERK } & \text { Extracellular signal-regulated kinase }\end{array}$




$\begin{array}{ll}\text { HIF } & \text { Hypoxia-inducible transcription factor } \\ \text { ICAM } & \text { Intracellular adhesion molecule } \\ \text { IL } & \text { Interleukin } \\ \text { IRF } & \text { Interferon regulatory factor } \\ \text { JNK } & \text { c-Jun N-terminal kinase } \\ \text { MAPKs } & \text { Mitogen-activated protein kinases } \\ \text { MIP } & \text { Macrophage inflammatory protein } \\ \text { MMA } & \text { Monomethylated arginine } \\ \text { NF-kB } & \text { Nuclear factor kB } \\ \text { NO } & \text { Nitric oxide } \\ \text { NOS } & \text { Nitric oxide synthase } \\ \text { PAMPs } & \text { Pathogen-associated molecular patterns } \\ \text { PKC } & \text { Protein kinase C } \\ \text { PPAR } & \text { Peroxisome proliferator-activator receptor } \\ \text { PRMT } & \text { Protein arginine methyltransferase } \\ \text { PTP } & \text { Protein tyrosine phosphatase } \\ \text { RTK } & \text { Receptor tyrosine kinase } \\ \text { SDMA } & \text { Symmetric dimethylarginine } \\ \text { Sp1 } & \text { Specificity protein 1 } \\ \text { TNF } & \text { Tumor necrosis factor } \\ \text { TRAF } & \text { TNF receptor associated factor } \\ \end{array}$

\section{References}

1. Kim, H.G.; Choi, S.; Lee, J.; Hong, Y.H.; Jeong, D.; Yoon, K.; Yoon, D.H.; Sung, G.-H.; Lee, S.; Hong, S. Src is a prime target inhibited by celtis choseniana methanol extract in its anti-inflammatory action. Evid. Based Complementary Altern. Med. 2018, 2018, 3909038. [CrossRef]

2. Nowarski, R.; Gagliani, N.; Huber, S.; Flavell, R.A. Innate immune cells in inflammation and cancer. Cancer Immunol. Res. 2013, 1, 77-84. [CrossRef] [PubMed]

3. Newton, K.; Dixit, V.M. Signaling in innate immunity and inflammation. Cold Spring Harb. Perspect. Biol. 2012, 4, a006049. [CrossRef] [PubMed]

4. Wang, A.; Al-Kuhlani, M.; Johnston, S.C.; Ojcius, D.M.; Chou, J.; Dean, D. Transcription factor complex AP-1 mediates inflammation initiated by C hlamydia pneumoniae infection. Cell. Microbiol. 2013, 15, 779-794. [CrossRef] [PubMed]

5. Han, S.Y.; Kim, J.; Kim, E.; Kim, S.H.; Seo, D.B.; Kim, J.H.; Shin, S.S.; Cho, J.Y. AKT-targeted anti-inflammatory activity of Panax ginseng calyx ethanolic extract. J. Ginseng Res. 2018, 42, 496-503. [CrossRef] [PubMed]

6. Cargnello, M.; Roux, P.P. Activation and function of the MAPKs and their substrates, the MAPK-activated protein kinases. Microbiol. Mol. Biol. Rev. 2011, 75, 50-83. [CrossRef]

7. Kim, E.; Yi, Y.S.; Son, Y.J.; Han, S.Y.; Kim, D.H.; Nam, G.; Hossain, M.A.; Kim, J.H.; Park, J.; Cho, J.Y. BIOGF1K, a compound K-rich fraction of ginseng, plays an antiinflammatory role by targeting an activator protein-1 signaling pathway in RAW264.7 macrophage-like cells. J. Ginseng Res. 2018, 42, 233-237. [CrossRef] [PubMed]

8. Yang, W.S.; Jeong, D.; Nam, G.; Yi, Y.-S.; Yoon, D.H.; Kim, T.W.; Park, Y.C.; Hwang, H.; Rhee, M.H.; Hong, S. AP-1 pathway-targeted inhibition of inflammatory responses in LPS-treated macrophages and EtOH/HCl-treated stomach by Archidendron clypearia methanol extract. J. Ethnopharmacol. 2013, 146, 637-644. [CrossRef]

9. Lawrence, T. The nuclear factor NF-кB pathway in inflammation. Cold Spring Harb. Perspect. Biol. 2009, 1, a001651. [CrossRef]

10. Straub, R.H.; Schradin, C. Chronic inflammatory systemic diseases: An evolutionary trade-off between acutely beneficial but chronically harmful programs. Evol. Med. Public Health 2016, 2016, 37-51. [CrossRef]

11. Ahuja, A.; Kim, J.H.; Kim, J.H.; Yi, Y.S.; Cho, J.Y. Functional role of ginseng-derived compounds in cancer. J. Ginseng Res. 2018, 42, 248-254. [CrossRef] [PubMed]

12. Li, S.; Yang, P.; Tian, E.; Zhang, H. Arginine methylation modulates autophagic degradation of PGL granules in C. elegans. Mol. Cell 2013, 52, 421-433. [CrossRef] [PubMed] 
13. Bedford, M.T.; Clarke, S.G. Protein arginine methylation in mammals: Who, what, and why. Mol. Cell 2009, 33, 1-13. [CrossRef]

14. Bachand, F. Protein arginine methyltransferases: From unicellular eukaryotes to humans. Eukaryot. Cell 2007, 6, 889-898. [CrossRef] [PubMed]

15. Blanc, R.S.; Richard, S. Arginine methylation: The coming of age. Mol. Cell 2017, 65, 8-24. [CrossRef]

16. Kim, J.H.; Yoo, B.C.; Yang, W.S.; Kim, E.; Hong, S.; Cho, J.Y. The role of protein arginine methyltransferases in inflammatory responses. Mediat. Inflamm. 2016, 2016, 4028353. [CrossRef]

17. Wei, H.; Mundade, R.; Lange, K.; Lu, T. Protein arginine methylation of non-histone proteins and its role in diseases. Cell Cycle 2014, 13, 32-41. [CrossRef]

18. Kim, D.-I.; Park, M.-J.; Choi, J.-H.; Kim, I.-S.; Han, H.-J.; Yoon, K.-C.; Park, S.-W.; Lee, M.-Y.; Oh, K.-S.; Park, S.-H. PRMT1 and PRMT4 regulate oxidative stress-induced retinal pigment epithelial cell damage in SIRT1-dependent and SIRT1-independent manners. Oxidative Med. Cell. Longev. 2015, 2015, 617919. [CrossRef]

19. Hata, K.; Yanase, N.; Sudo, K.; Kiyonari, H.; Mukumoto, Y.; Mizuguchi, J.; Yokosuka, T. Differential regulation of T-cell dependent and T-cell independent antibody responses through arginine methyltransferase PRMT 1 in vivo. FEBS Lett. 2016, 590, 1200-1210. [CrossRef]

20. Liu, L.; Sun, Q.; Bao, R.; Roth, M.; Zhong, B.; Lan, X.; Tian, J.; He, Q.; Li, D.; Sun, J. Specific regulation of PRMT1 expression by PIAS1 and RKIP in BEAS-2B epithelia cells and HFL-1 fibroblasts in lung inflammation. Sci. Rep. 2016, 6, 1-13. [CrossRef]

21. Brooks, W.H.; Le Dantec, C.; Pers, J.-O.; Youinou, P.; Renaudineau, Y. Epigenetics and autoimmunity. J. Autoimmun. 2010, 34, J207-J219. [CrossRef] [PubMed]

22. Kaczmarek, K.; Clifford, R.; Patel, J.; Shaw, D.; Dowden, J.; Knox, A. The role of protein arginine N-Methyltransferase 1 (PRMT1) in inflammatory gene expression of airway smooth muscle cells in asthma, D58. In Airways Hyperresponsiveness: Novel Mechanisms And Targets; American Thoracic Society: New York, NY, USA, 2018; p. A7264.

23. Liu, H.; Jiang, J.; Zhao, L. Protein arginine methyltransferase-1 deficiency restrains depression-like behavior of mice by inhibiting inflammation and oxidative stress via Nrf-2. Biochem. Biophys. Res. Commun. 2019, 518, 430-437. [CrossRef] [PubMed]

24. Fan, Z.; Li, J.; Li, P.; Ye, Q.; Xu, H.; Wu, X.; Xu, Y. Protein arginine methyltransferase 1 (PRMT1) represses MHC II transcription in macrophages by methylating CIITA. Sci. Rep. 2017, 7, 1-9. [CrossRef] [PubMed]

25. Tikhanovich, I.; Zhao, J.; Olson, J.; Adams, A.; Taylor, R.; Bridges, B.; Marshall, L.; Roberts, B.; Weinman, S.A. Protein arginine methyltransferase 1 modulates innate immune responses through regulation of peroxisome proliferator-activated receptor $\gamma$-dependent macrophage differentiation. J. Biol. Chem. 2017, 292, 6882-6894. [CrossRef] [PubMed]

26. Zhang, J.; Qian, K.; Yan, C.; He, M.; Jassim, B.A.; Ivanov, I.; Zheng, Y.G. Discovery of decamidine as a new and potent PRMT1 inhibitor. MedChem Comm 2017, 8, 440-444. [CrossRef] [PubMed]

27. Yang, H.; Ouyang, Y.; Ma, H.; Cong, H.; Zhuang, C.; Lok, W.-T.; Wang, Z.; Zhu, X.; Sun, Y.; Hong, W. Design and synthesis of novel PRMT1 inhibitors and investigation of their binding preferences using molecular modelling. Bioorganic Med. Chem. Lett. 2017, 27, 4635-4642. [CrossRef] [PubMed]

28. Bissinger, E.-M.; Heinke, R.; Spannhoff, A.; Eberlin, A.; Metzger, E.; Cura, V.; Hassenboehler, P.; Cavarelli, J.; Schüle, R.; Bedford, M.T. Acyl derivatives of p-aminosulfonamides and dapsone as new inhibitors of the arginine methyltransferase hPRMT1. Bioorganic Med. Chem. 2011, 19, 3717-3731. [CrossRef]

29. Sun, Q.; Liu, L.; Mandal, J.; Molino, A.; Stolz, D.; Tamm, M.; Lu, S.; Roth, M. PDGF-BB induces PRMT1 expression through ERK1/2 dependent STAT1 activation and regulates remodeling in primary human lung fibroblasts. Cell. Signal. 2016, 28, 307-315. [CrossRef]

30. Xia, L.; Zhang, H.-X.; Xing, M.-L.; Xu, Y.-B.; Li, P.; Huang, L.-K.; Bai, J.; Tian, Z.; Zhao, Z.-D. Knockdown of prmt1 suppresses il-1 $\beta$-induced cartilage degradation and inflammatory responses in human chondrocytes through gli1-mediated hedgehog signaling pathway. Mol. Cell. Biochem. 2018, 438, 17-24. [CrossRef]

31. Intayoung, P.; Limtrakul, P.; Yodkeeree, S. Antiinflammatory activities of crebanine by inhibition of NF- $k B$ and AP-1 activation through suppressing MAPKs and Akt signaling in LPS-induced RAW264. 7 macrophages. Biol. Pharm. Bull. 2016, 39, 54-61. [CrossRef] 
32. Hossen, M.J.; Hong, Y.D.; Baek, K.S.; Yoo, S.; Hong, Y.H.; Kim, J.H.; Lee, J.O.; Kim, D.; Park, J.; Cho, J.Y. In vitro antioxidative and anti-inflammatory effects of the compound K-rich fraction BIOGF1K, prepared from Panax ginseng. J. Ginseng Res. 2017, 41, 43-51. [CrossRef] [PubMed]

33. Karin, M. The regulation of AP-1 activity by mitogen-activated protein kinases. J. Biol. Chem. 1995, 270, 16483-16486. [CrossRef] [PubMed]

34. Thompson, C.; Frazier-Jessen, M.; Rawat, R.; Nordan, R.; Brown, R. Evaluation of methods for transient transfection of a murine macrophage cell line, RAW 264.7. Biotechniques 1999, 27, 824-832. [CrossRef] [PubMed]

35. Cheung, S.T.; Shakibakho, S.; So, E.Y.; Mui, A.L. Transfecting RAW264. 7 cells with a luciferase reporter gene. JoVE 2015, e52807. [CrossRef]

36. Yao, Q.; Liu, J.; Zhang, Z.; Li, F.; Zhang, C.; Lai, B.; Xiao, L.; Wang, N. Peroxisome proliferator-activated receptor $\gamma(\operatorname{PPAR} \gamma)$ induces the gene expression of integrin $\alpha(\mathrm{V}) \beta(5)$ to promote macrophage M2 polarization. J. Biol. Chem. 2018, 293, 16572-16582. [CrossRef]

37. Zhao, J.; O'Neil, M.; Vittal, A.; Weinman, S.A.; Tikhanovich, I. PRMT1-dependent macrophage IL-6 production is required for alcohol-induced HCC progression. Gene Expr. 2019, 19, 137-150. [CrossRef]

38. Lafleur, V.N.; Richard, S.; Richard, D.E. Transcriptional repression of hypoxia-inducible factor-1 (HIF-1) by the protein arginine methyltransferase PRMT1. Mol. Biol. Cell 2014, 25, 925-935. [CrossRef]

39. Davies, C.C.; Chakraborty, A.; Diefenbacher, M.E.; Skehel, M.; Behrens, A. Arginine methylation of the c-Jun coactivator RACO-1 is required for c-Jun/AP-1 activation. EMBO J. 2013, 32, 1556-1567. [CrossRef]

40. Byeon, S.E.; Yi, Y.-S.; Oh, J.; Yoo, B.C.; Hong, S.; Cho, J.Y. The role of Src kinase in macrophage-mediated inflammatory responses. Mediat. Inflamm. 2012, 2012. [CrossRef]

41. Kim, M.S.; Yoo, B.C.; Yang, W.S.; Han, S.Y.; Jeong, D.; Song, J.M.; Kim, K.H.; Aravinthan, A.; Kim, J.H.; $\mathrm{Kim}, \mathrm{J} . \mathrm{-H}$. Src is the primary target of aripiprazole, an atypical antipsychotic drug, in its anti-tumor action. Oncotarget 2018, 9, 5979. [CrossRef]

42. Zheng, X.M.; Resnick, R.J.; Shalloway, D. A phosphotyrosine displacement mechanism for activation of Src by PTP $\alpha$. EMBO J. 2000, 19, 964-978. [CrossRef] [PubMed]

43. Roskoski, R., Jr. Src kinase regulation by phosphorylation and dephosphorylation. Biochem. Biophys. Res. Commun. 2005, 331, 1-14. [CrossRef] [PubMed]

44. Meng, Y.; Roux, B. Locking the active conformation of c-Src kinase through the phosphorylation of the activation loop. J. Mol. Biol. 2014, 426, 423-435. [CrossRef] [PubMed]

45. Parsons, S.J.; Parsons, J.T. Src family kinases, key regulators of signal transduction. Oncogene 2004, 23, 7906-7909. [CrossRef]

46. Liu, A.; Gong, P.; Hyun, S.W.; Wang, K.Z.; Cates, E.A.; Perkins, D.; Bannerman, D.D.; Puché, A.C.; Toshchakov, V.Y.; Fang, S. TRAF6 couples TLR4 signaling to Src family kinase activation and opening of the paracellular pathway in human lung microvascular endothelia. J. Biol. Chem. 2012. [CrossRef]

47. Park, G.; Kim, E.; Son, Y.-J.; Yoon, D.H.; Sung, G.-H.; Aravinthan, A.; Park, Y.C.; Kim, J.-H.; Cho, J.Y. Anti-inflammatory effect of torilidis fructus ethanol extract through inhibition of Src. Pharm. Biol. 2017, 55, 2074-2082. [CrossRef]

48. Sun, Q.; Liu, L.; Roth, M.; Tian, J.; He, Q.; Zhong, B.; Bao, R.; Lan, X.; Jiang, C.; Sun, J. PRMT1 upregulated by epithelial proinflammatory cytokines participates in COX2 expression in fibroblasts and chronic antigen-induced pulmonary inflammation. J. Immunol. 2015, 195, 298-306. [CrossRef]

49. Li, T.; Kong, A.-N.T.; Ma, Z.; Liu, H.; Liu, P.; Xiao, Y.; Jiang, X.; Wang, L. Protein arginine methyltransferase 1 may be involved in pregnane $x$ receptor-activated overexpression of multidrug resistance 1 gene during acquired multidrug resistant. Oncotarget 2016, 7, 20236. [CrossRef]

50. Boykin, D.W. Antimicrobial activity of the DNA minor groove binders furamidine and analogs. J. Braz. Chem. Soc. 2002, 13, 763-771. [CrossRef]

51. Hu, H.; Qian, K.; Ho, M.-C.; Zheng, Y.G. Small molecule inhibitors of protein arginine methyltransferases. Expert Opin. Investig. Drugs 2016, 25, 335-358. [CrossRef]

52. Su, H.; Liu, S.-M.; Sun, C.-W.; Bedford, M.T.; Zhao, X. Protein Arginine Methyltransferase 1 (PRMT1) Dampens Self-Renewal and Promotes Differentiation of Hematopoietic Stem Cells in Mouse Models; American Society of Hematology: Washington, DC, USA, 2019. 
53. Bayen, S.; Saini, S.; Gaur, P.; Duraisamy, A.J.; Sharma, A.K.; Pal, K.; Vats, P.; Singh, S.B. PRMT1 promotes hyperglycemia in a FoxO1-dependent manner, affecting glucose metabolism, during hypobaric hypoxia exposure, in rat model. Endocrine 2018, 59, 151-163. [CrossRef] [PubMed]

54. Shen, N.Y.; Ng, S.Y.; Toepp, S.L.; Ljubicic, V. Protein arginine methyltransferase expression and activity during myogenesis. Biosci. Rep. 2018, 38, BSR20171533. [CrossRef] [PubMed]

55. Xiao, H.-B.; Sui, G.-G.; Lu, X.-Y.; Sun, Z.-L. Elevated levels of ADMA are associated with lower DDAH2 and higher PRMT1 in LPS-induced endometritis rats. Inflammation 2018, 41, 299-306. [CrossRef] [PubMed]

56. Jung, Y.Y.; Hong, J.T.; Han, S.B.; Park, Y.H.; Son, D.J. Effect of Ixeris dentata Nakai extract on nitric oxide production and prostaglandin E2 generation in LPS-stimulated RAW264. 7 Cells. Immune Netw. 2015, 15, 325-330. [CrossRef] [PubMed]

57. Lee, J.-O.; Yang, W.S.; Park, J.G.; Jeong, D.; Kim, H.G.; Yoon, K.D.; Aravinthan, A.; Kim, J.-H.; Kim, E.; Cho, J.Y. Src and Syk contribute to the anti-inflammatory activities of Achyranthes aspera ethanolic extract. J. Ethnopharmacol. 2017, 206, 1-7. [CrossRef] [PubMed]

58. Byeon, S.E.; Chung, J.Y.; Lee, Y.G.; Kim, B.H.; Kim, K.H.; Cho, J.Y. In vitro and in vivo anti-inflammatory effects of taheebo, a water extract from the inner bark of Tabebuia avellanedae. J. Ethnopharmacol. 2008, 119, 145-152. [CrossRef]

59. Choi, E.; Kim, E.; Kim, J.H.; Yoon, K.; Kim, S.; Lee, J.; Cho, J.Y. AKT1-targeted proapoptotic activity of compound K in human breast cancer cells. J. Ginseng Res. 2019, 43, 692-698. [CrossRef]

60. Baek, K.-S.; Yi, Y.-S.; Son, Y.-J.; Yoo, S.; Sung, N.Y.; Kim, Y.; Hong, S.; Aravinthan, A.; Kim, J.-H.; Cho, J.Y. In vitro and in vivo anti-inflammatory activities of Korean Red Ginseng-derived components. J. Ginseng Res. 2016, 40, 437-444. [CrossRef]

61. Sung, N.Y.; Kim, M.-Y.; Cho, J.Y. Scutellarein reduces inflammatory responses by inhibiting Src kinase activity. Korean J. Physiol. Pharmacol. 2015, 19, 441-449. [CrossRef]

62. Burnette, W.N. "Western blotting": Electrophoretic transfer of proteins from sodium dodecyl sulfate-polyacrylamide gels to unmodified nitrocellulose and radiographic detection with antibody and radioiodinated protein A. Anal. Biochem. 1981, 112, 195-203. [CrossRef]

(C) 2020 by the authors. Licensee MDPI, Basel, Switzerland. This article is an open access article distributed under the terms and conditions of the Creative Commons Attribution (CC BY) license (http://creativecommons.org/licenses/by/4.0/). 